\title{
MULTICULTURAL EFFECTS IN THE ARCHITECTURE
}

\author{
Hajnalka JUHÁSZ, ${ }^{1}$ Balázs KÓSA, ${ }^{2}$ Tamás MOLNÁR ${ }^{3}$ \\ ${ }^{1}$ University of Pécs, Faculty of Engineering and Information Technology, Marcel Breuer Doctoral School, \\ Pécs, Hungary, hjuhasz91@gmail.com \\ ${ }^{2}$ University of Pécs, Faculty of Engineering and Information Technology, Department of Interior Applied \\ and Creative Design, Pécs, Hungary, kosa.balazs.84@gmail.com \\ ${ }^{3}$ University of Pécs, Faculty of Engineering and Information Technology, Department of Visual Studies, \\ Pécs, Hungary, tmolnar@mik.pte.hu
}

\begin{abstract}
Many scientific fields deal with the topic of multiculturalism which is gradually becoming a characteristic of the $21^{\text {th }}$ century. When we examine culturally mixed societies, we compare different expectations that come as results of different habits. A goal in architecture is to respond to these different expectations, to adapt to new situations. In our research we examine the city of Pécs and its university in order to create a design concept for a new multi-belief sacred space.
\end{abstract}

Keywords: multiculturalism, multi-belief spaces, architecture, Pécs.

\section{Introduction}

\subsection{Statement of intention}

Nowadays, due to the accelerated flow of information we observe a great number of influences that transcend our traditional borders. Thus, our connections to countries and places become loose, our perspectives are broader which brings about the mingling of societies that used to organize themselves primarily on religious, later on national principles. The notion of multiculturalism appears with increasing frequency in many fields of science, also in architecture since it concerns the shaping of both our natural and artificial environment.

In previous ages, the mixture of different cultures could take place in two main ways: by the oppressive policies of conquering forces, or in the mixed communities that were the result of different settlements or colonizations. In such cases the majority and minority cultures often worked side by side with no significant conflicts, moreover sometimes they borrowed each other's technical and formal solutions.

Keeping this in mind, the multiculturalism that we discuss below regards neither the total domi- nance of the majority culture nor a merging of different cultural traditions into one to be a solution; instead it assumes that each group retains and cultivates its own culture without any hindrance. In our research we examine the culturalyly mixed settlement and cities, while focusing on the directional development of the architectural formal language, comparing real functions and needs. We also bring into focus the conceptual development of a particular building in a multi-cultural environment.

\section{The situation of Pécs}

\subsection{Historical background}

AHistorically the appreciation of a settlement happened according to at least one of the following aspects: religious, economic and/or strategic. In time, clusters that gained importance due to these aspects became characterized by the cohabitance of several different cultures, each of which expanded by applying its own architectural formal language. These aspects are clearly visible in Pécs with its surroundings, a city that by now has become the center of the Southern region of Hungary below the Danube, having many 
architectural edifices that show specific cultural features or - in the worst case - remains of such edifices. From the viewpoint of heritage protection, such buildings were, for example, the burial chambers that preserved ancient Christian burial practices; as well as the Turkish monuments (mosques, ruins of baths, tombs etc.) and while those reflect the architecture of a conquering power, they have nevertheless become a symbol of the city of Pécs and they make the city's architectural environment even more valuable. These monuments are officially recorded World Heritage sites. Besides a large number of different archeological and historical researches, the exploration and salvaging of these buildings by means of modern architectural and technical solutions was also supported.

\subsection{Present condition}

Higher education in Pécs, is one of the other environments where different cultures meet. The University of Pécs has contacts with a large number of foreign institutions, in the case of the Faculty of Engineering and Information Technology this means 56 partner institutions in 24 countries all around the world.

As a result in the past decade architectural design has also been concerned with buildings that can serve as meeting places between different cultures. In the case of Pécs such places are among others - the University's faculty buildings and those of its associated research institutes.

In the past ten years the constantly growing number of foreign students has posed the question: how can these students, coming from different countries, practice their own cultural habits in our country which to them is a foreign environment? The most obvious aspect of this is the question of religious practice.

Nowadays, as a result of globalization, the concept of multi-religious spaces is becoming less and less unusual and the development of such buildings is also growing in scale. In this case the function is not based on the specific characteristics of any religious practice but rather on contemplation; the specifics of the particular religions are considered only in a later phase of the planning process.

Based on a detailed analysis presented in an earlier study, we assume that its conclusion is right, namely that perfect neutrality between religions in a multi-religious space is almost impossible. Nevertheless, if we consider certain aspects (such as gender separation or the need for certain postures during worship), we have a good chance to create an environment that is ideal for its users, a

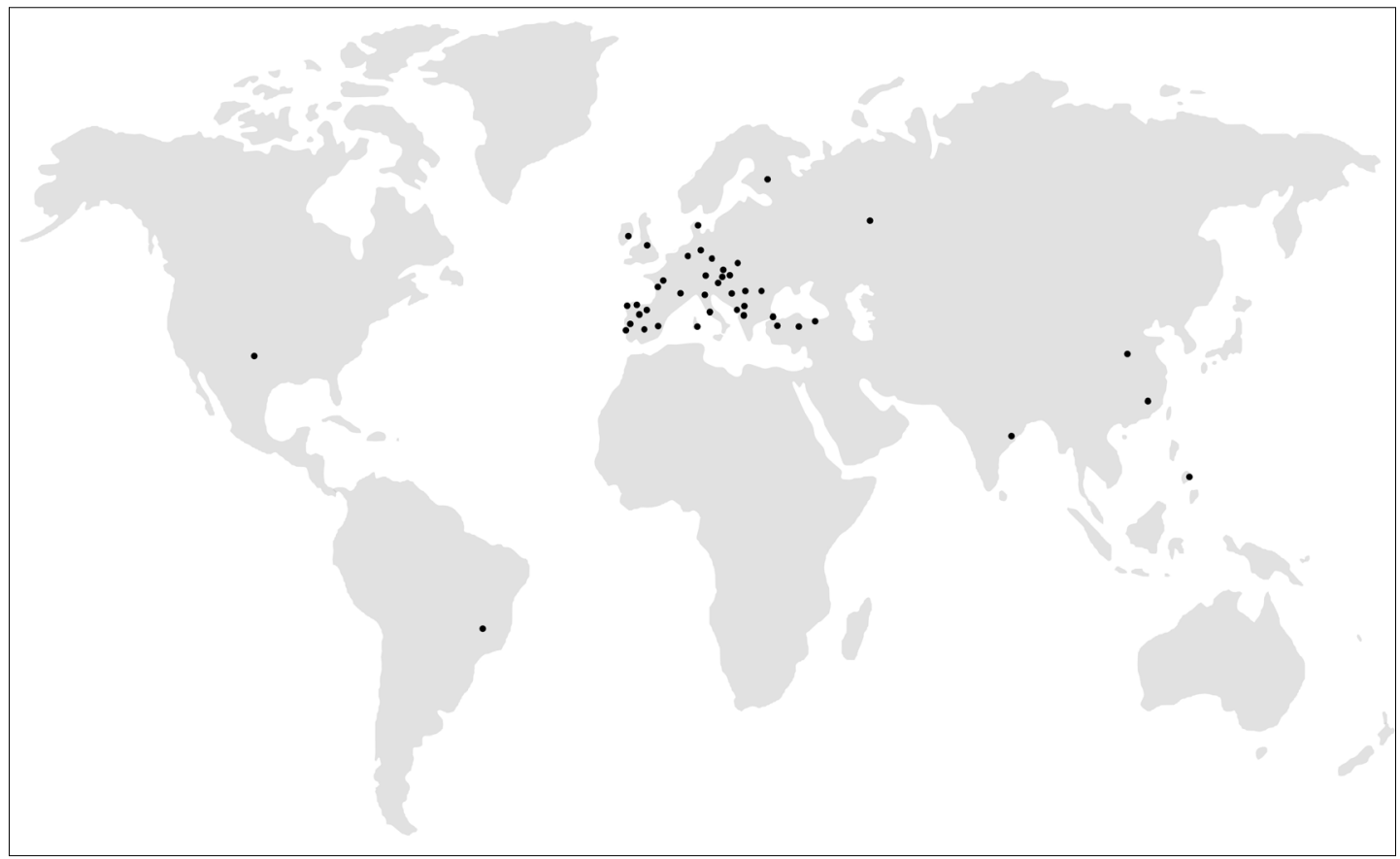

Figure 1. University of Pécs Faculty of Engineering and Information Technology has partner institutions in 24 countries around the world 
Table 1. Distribution of foreign students at the University of Pécs; Faculty of Engineering and Information Technology in the last five years (when this table was compiled the data regarding 2018. was not available yet).

\begin{tabular}{|l|c|c|c|c|}
\hline Year & PTE MIK & Hungarian & Foreign & $\begin{array}{c}\text { Foreign } \\
\%\end{array}$ \\
\hline 2013 & 2851 & 2799 & 52 & 1,82 \\
\hline 2014 & 2466 & 2374 & 92 & 3,73 \\
\hline 2015 & 2356 & 2179 & 174 & 7,39 \\
\hline 2016 & 2302 & 2047 & 266 & 11,08 \\
\hline 2017 & 2383 & 2018 & 365 & 15,32 \\
\hline
\end{tabular}

multi-belief space that is suitable for quiet reflection and will not lead to cultural conflicts.

Regarding the situation of foreign students who study in Pécs for several years, based on their increasing number, we conclude that there is a real demand for a so-called "neutral chapel" which can provide appropriate space for meditation and individual religious practice, worship.

However, in our study of the problem, the solution proved to be not in the combination of the specific characteristics of the different religions but the complex approach to space use. That is where the basis for the whole planning process was given by the changing needs, divided spaces, orientation and the possibility of separation in time, furthermore, the interior shaping of the designed space and the correct interpretation of the formal languages.

\section{Conclusions}

As a result of our research, we have come to the conclusion that the cultural definition of a city cannot be simplified to the notions that represent a single majority group (a nation for instance). At the same time, the people's attitudes towards a foreign culture show a different pattern in a community where a mixed cultural environment was present in the past too, as is the case of Pécs.

In our current state due to the effects of globalization, we encounter with increasing frequency situations where the multicultural influences become common and their results can be mapped objectively in certain fields of science, as is the case in architecture.

Based on the cultural diversity of the students at the University of Pécs, this paper formulates the need for a "chapel" corresponding to the exigencies of many different religions, which can function
Table 2. The first ten countries of origin of foreign students, excepting neighboring countries (2014. autumn)

\begin{tabular}{|l|c|}
\hline \multicolumn{2}{|c|}{ University of Pécs } \\
\hline Country & Foreign students \\
\hline Norwany & 691 \\
\hline Iran & 267 \\
\hline China & 200 \\
\hline Spain & 125 \\
\hline Jordan & 105 \\
\hline Republic of Korea & 90 \\
\hline Brazil & 87 \\
\hline Turkey & 60 \\
\hline Sweden & 51 \\
\hline
\end{tabular}

as a place for individual worship and also for silent meditation in the case of individuals who do not belong to any particular religion. This study is the first step of a conceptually based design program in order to create a small-scaled multi-belief space which we hope to build in the future..

\section{References}

[1] Majtényi Balázs: A nemzetállam új ruhája. Multikulturalizmus Magyarországon. Gondolat Kiadó, Budapest, 2007. 23-39.

[2] Francisco Díez de Velasco: Multi-belief/Multi-faith Spaces: Theoretical Proposals for a Neutral and Operational Design. RECODE - Responding to Complex Diversity in Europe and Canada. 2014. Online Working Paper 26. (accessed on $5^{\text {th }}$ February 2019).

http://www.recode.info/wp-content/uploads/2014/01/FINAL-26-D\%C3\%ADez-de-Velasco_fin.pdf

[3] Francisco Colom Gonzalez \& Gianni D'Amato (Eds.): Multi-belief/Multi-faith Spaces: Theoretical Proposals for a Neutral and Operational Design. In: Multireligious Society: Dealing with Religious Diversity in Theory and Practice. Ashgate/Routledge, 2017. 236-250. (accessed on: $8^{\text {th }}$ February 2019.)

https://www.researchgate.net/publication/313930537_Multi-beliefMulti-faith_Spaces_ Theoretical_Proposals_for_a_Neutral_and_Operational_Design_en_Francisco_Co-lom_Gonzalez_Gianni_D'Amato_Eds_Multireligious_Society_ Dealing_with_Religious_Diversity_in_Theo

[4] Pécsi Tudományegyetem: Tények/ adatok/ statisztikák. (accessed on: $8^{\text {th }}$ February 2019.)

https://pte.hu/tenyek_adatok/statisztikak 
[5] Wusching Á. T.: A nemzetközi hallgatók tanulmányi célú mobilitásának jellegzetességei Pécs és Debrecen példáján. Tér és Társadalom, 31/2. (2017). 69-72.

https://doi.org/10.17649/TET.31.2.2828

[6] 100Egedy G.: A multikulturalizmus dilemmái: Nagy-Britannia példája. 2006. (accessed on: $8^{\text {th }}$ February 2019.)

https://polgariszemle.hu/archivum/23-2006-junius-2-evfolyam-6-szam/106-a-multikulturalizmus-dilemmai-nagy-britannia-peldaja\#note2 